\title{
EDUCATION AS HARMONY INTELLIGENCE AND HEALTH
}

\author{
Sergii Boltivets \\ Clinic of Active Therapy of the Original States, Ukraine \\ E-mail: boltivetssergij@i.ua
}

The emergence of a public request for the realization of special abilities of a person, focused on children, is typical for countries where awareness of their own intellectual backwardness has become a consequence of comparison with others. This is the so-called post-totalitarian or, more specifically, post-communist countries, different from the free world, as thoroughly proved by the study "Psychotherapy in the Western World and in the USSR" (1973) by one of the most prominent hypnotherapists and psychotherapists of the world Dr. Eugene Hlywa (Sydney, Australia). In particular, a definite stature, inherent in every human population, the aggregate of the capacities of people's abilities is roughly equal in each country. However, the countries of the free world, by their freedom of expression and respect for this individual self-expression, create conditions for the implementation of any capacities of abilities, while totalitarian - only conditions for a relatively small number of able people, sufficient to serve the interests of the ruling elite. Everyone else, as it was already in the history of Ukraine at the beginning of the 20th century, was destroyed: most Ukrainian kobzars were shot at Kharkiv, Ukrainian poets, writers and playwrights - shot in the Sandarmokh Karelian tract, etc. Comparison of ancient Greek cities confirms the vitality of Athens as a city of free prosperity of human abilities and the decline of Sparta, which served as an example of a state organization for future communist and national-socialist leaders of the USSR and the Third Reich.

I have a duty to pay close attention to this: the life of every society can be fulfilled only through the free development of all the capacities of every person genetically transferred to her parents, grandparents, great-grandparents, great-grandparents and great-grandparents, to all the ancestors of the genus, other genera, of which every nation is naturally formed, is not artificially collected by the use of someone's political will, which was artificially created by the community of the "Soviet people." Given the cultivated migration or the forced eviction of many peoples of the former USSR, these people lost the harmony of their own lives, and therefore they turned from the people to Nabrida - the crowd, the crowd of typed human beings, the instinct of self-preservation of which is the loss of an ethnic, by birth, generic, and with it and own personal personality, abandoning the uniqueness of their own development.

Why does the incarnation and development of the whole variety of individual abilities save lives? It is precisely because the diversity of life and periods that require the joint efforts of many people leads to the manifestation of unpredictable, sometimes incredible human abilities - selfsacrifice, savagery, endurance, understanding, and countless numbers of properties embodied in acts that sustain the lives of others - become models. the culture of the life of each people.

The modern social concept of understanding human giftedness, restoring the etymology of the primitive Latin meanings of the concept - concepto, conceptum, conceptus, conception, fertilization, uterine fruit, reflecting the general social desire to restore the harmony of life that has been affected by the Russian colonization of Ukraine over the past three centuries. But - this is just the germ of understanding, denoted by the metaphorical notion of "giftedness", "gifted child" just as the German culture expressed this social need by the metaphor of the "wunderkind": a miracle child, a French: "infanta teibl" - an intolerable, terrible child, which may be the future genius. 
The metaphor of "giftedness" and "giftedness" already contains the meaning of "gift" in the root token, and hence the gift of a child without applying her own efforts to father and mother, and with them - countless generations of ancestors, that is, it is laid down genuinely. In this sense, it is about the possibilities of abilities, and not the ability themselves, that is, the ability to implement them by their own efforts, and not the unconditional prepare this "gift" to consume, use or share it. The same goes for "gift-germ", "gift concept", and not "gift of destiny", which may not be as favorable as it would be desirable.

As noted by more than a century ago, the prominent Kiev psychologist and psychiatrist Ivan Sikorsky, the father of the future American aircraft designer Igor Sikorsky, in his work «The wisdom and talent in the light of objective research according to psychophysiological correlations,» the pulse and breath of intellectually gifted people differed more precisely in expressiveness only to their inherent characteristics, and to people mediocre, undersown inherent in the indistinct, undefined rhythm of pulse and respiration and, by this sign, events bless one another within this category of surveyed (Sikorskij, 1912).

In other words, expressing the exact contemporary psychological terminology, especially peculiarities of human abilities, including in childhood, can be detected - observed or recorded only in activity, even if it is psychophysiological activity of an organism.

However, it should be borne in mind that the psycho-physiological functioning of the organism is a consequence, a reflection of the development of realized or realized to a certain extent psychophysical capacities as much as they are expressed. And for this purpose, individual efforts are required - the energy that human will direct to the realization of one's own life.

The individual gift of each person is her life, a shared gift - the harmony of this life, which is always carried out by people's efforts to co-incarnate their abilities and talents, and their diversity corresponds to the total population of the Earth, which according to the report on the global demographic situation and prospects for its change, prepared by the Department on economic and social issues of the UN Secretariat, currently stands at 7.6 billion people, and by 2030 will increase by one billion - to 8.6 billion people, in particular, due to an increase in the average prolonged those lives (Naselennja Zemli stanovit' 7,6 mlrd osib - OON, 2017).

There is a logical question: the gift of life, which every person is entrusted with safeguarding, relates to her giftedness with this life or to the implementation of her genetically predetermined capabilities, which are embodied in the lifelong development of the necessary abilities for this? Do young parents think the same way, prompting them to identify the child's partial abilities, even if their demand is given at the cost of health?

Specialists of the majority of human-knowledge branches of knowledge are unanimous in that metaphorically presented in modern social consciousness giftedness - an integrative personality. Psychophysiological integration, in particular the activity of both cerebral hemispheres, auditory, visual, motor and other means of information perception, harmonization of higher nervous activity enables children to develop harmoniously: physically, mentally, aesthetically, spiritually, socially and contributes to the formation of their innate natural abilities and talents, creates conditions for success in learning and life.

The multidimensional multisensory way of perception and assimilation of educational information allows to achieve a high level of intellectual development of children, their sociability, interest in learning and knowledge of the surrounding world. This contributes to preventing in the early adolescence the intellectual and social desynchrony of daily life functioning, which in the most massive embodiment is expressed in the Internet addiction, manifestations of bad habits and trains. A characteristic feature of gifted children in the process of realizing their abilities is often the uneven development of mental processes, among which - the obvious predominance of intellectual abilities over communicative, consisting in specific behavior: the avoidance of uninteresting for them peers and adults, using specific ways of communication, such as, for example, more using the Internet, rather than directly.

Talent is always unique and therefore only this uniqueness can attract a child with special abilities that seeks to realize them.

The discussions of the middle of the twentieth century on "physicists and lyricists", the specialization of the development of abilities of the child already in the early stages of its de- 
velopment, remained in the last century, since the overwhelming part of the conducted at this time and later psychological experiments clearly showed: the ability to integrate, the majority of those children who were specially selected for physical and mathematical classes, in the process of learning revealed even more expressive literary talents than put in a deadlock those who took them. Moreover, the abilities of the child are rapidly changing the direction of their application: of all children selected in Ukraine for training in specialized classes of chemical profile in the first half of the 60 years of the twentieth century, since it was then believed that the chemist - the profession of the future, no student after school did choose any of the chemical faculties of higher education and, moreover, a profession associated with chemistry.

That is why the literary ability is an inexhaustible transformation of the unprecedented into a poetic celebration - to poetry for people and people. Human gifted as a pledge of birth has an unpredictable number of ways, paths and paths of its pursuit and lifelong transformations that are unpredictable in advance, all of which unites the distinction from the already known and accomplished, the uniqueness of the psycho-physiological and spiritual self-movement to the realization of one's own life purpose.

\section{References}

Naselennja Zemli stanovit' 7,6 mlrd osib - OON (2017). Ukraïns'ki nacional'ni novini: informacijne agenstvo [Elektronnij resurs] [The population of the Earth is 7.6 billion people - UN / Ukrainian national news: information agency]. Retrieved from http://www.unn.com.ua/uk/news/1672177-naselennya-zemlistanovit-7-6-mlrd-osib-oon

Sikorskij, I. A. (1912). Darovitost' i talantlivost'v svete ob»ektivnogo issledovanija po dannym psihofizicheskih korreljativov [Giftedness and talent in the light of objective research according to psychophysical correlative data]. Kiev: Tip. S.V.Kul'zhenko, p. 30.

Received: November 22, 2018

Accepted: December 19, 2018 